\title{
Nutrient and anti-nutrient composition of processed crayfish (Atya gabonensis) from river Benue, Nigeria.
}

\section{Composición de nutrientes y antinutrientes del cangrejo de río procesado (Atya gabonensis) del río Benue, Nigeria.}

\author{
I.M. Iwar*, \& C.M. Amu \\ Department of Wildlife and Range Management, Federal University of Agriculture, Makurdi, \\ Nigeria \\ Corresponding Author: +2347030857281; E-mail: michaeliwar@uam.edu.ng / \\ michaeliwar@gmail.com
}

\begin{abstract}
The species of crayfish identified as (Atya gabonensis) along River Benue Nigeria and were captured and analyzed for nutrient and antinutrient content including, proximate composition (crude protein, crude fat, crude fiber, ash, and moisture content), as well as vitamin A, Vitamin B components, Vitamin C, Vitamin D, vitamin E, Vitamin $\mathrm{K}$ and select mineral concentrations. Additionally, some important antinutrients in crayfish were also examined. The proximate composition showed that moisture content was $(9.54 \%)$, protein was $(7.46 \%)$, Crude fibre was (5.60\%), fat was $(1.57 \%)$ and ash was $(2.47 \%)$ respectively. This was found to be rich in protein and considerably high amount of moisture content. The anti-nutrient composition analysis revealed the presence of Saponin $(0.471 \mathrm{mg} / 100 \mathrm{~g})$, Alkaloid $(3.905 \mathrm{mg} / 100 \mathrm{~g})$, flavonoid $(0.675 \mathrm{mg} / 100 \mathrm{~g})$, tannin $(0.017 \mathrm{mg} / 100 \mathrm{~g})$, Phytate $(0.060 \mathrm{mg} / 100 \mathrm{~g})$, Oxalate $(0.005 \mathrm{mg} / 100 \mathrm{~g})$ and others, all of which are below toxic level. For mineral and vitamin compositions, potassium was significantly $(P>0.05)$ higher than iron, zinc, magnesium, calcium and phosphorus while vitamin $C$ was $(4.920 \mathrm{mg} / 100 \mathrm{~g})$ which is higher than all other vitamins evaluated. Based on these findings crayfish (Atya gabonensis) is recommended for consumption and for further investigation as a potential raw material for the pharmaceutical industry.
\end{abstract}

Keywords: Atya gabonensis, Nutrient, Anti nutrient, River Benue,composition 
Sustainability, Agri, Food and Environmental Research, (ISSN: 0719-3726), 9(2), 2021: 205-215 http://dx.doi.org/10.7770/safer-V0N0-art2257

\section{RESUMEN}

Las especies de cangrejo de río identificadas como (Atya gabonensis) a lo largo del río Benue Nigeria y se capturaron y analizaron para determinar el contenido de nutrientes y antinutrientes, incluida la composición aproximada (proteína cruda, grasa cruda, fibra cruda, cenizas y contenido de humedad), así como vitamina A, Componentes de vitamina B, vitamina $C$, vitamina $\mathrm{D}$, vitamina $\mathrm{E}$, vitamina $\mathrm{K}$ y concentraciones de minerales seleccionadas. Además, también se examinaron algunos antinutrientes importantes en los cangrejos de río. La composición aproximada mostró que el contenido de humedad fue (9.54\%), la proteína fue $(7.46 \%)$, la fibra cruda fue $(5.60 \%)$, la grasa fue $(1.57 \%)$ y la ceniza fue $(2.47 \%)$ respectivamente. Se encontró que era rico en proteínas y una cantidad considerablemente alta de contenido de humedad. El análisis de composición antinutrientes reveló la presencia de saponina $(0,471 \mathrm{mg} / 100 \mathrm{~g})$, alcaloide $(3,905 \mathrm{mg} / 100 \mathrm{~g})$, flavonoide $(0,675 \mathrm{mg} / 100$ g), tanino $(0,017 \mathrm{mg} / 100 \mathrm{~g})$, fitato $(0,060 \mathrm{mg} / 100 \mathrm{~g})$, Oxalato $(0,005 \mathrm{mg} / 100 \mathrm{~g})$ y otros, todos los cuales están por debajo del nivel tóxico. Para las composiciones de minerales y vitaminas, el potasio fue significativamente ( $P>0.05)$ más alto que el hierro, zinc, magnesio, calcio y fósforo, mientras que la vitamina C fue $(4.920 \mathrm{mg} / 100 \mathrm{~g})$ que es más alta que todas las demás vitaminas evaluadas. Sobre la base de estos hallazgos, se recomienda el consumo de cangrejo de río (Atya gabonensis) y para su posterior investigación como materia prima potencial para la industria farmacéutica.

Palabras clave: Atya gabonensis, Nutriente, Antinutriente, Río Benue, composición

\section{INTRODUCTION}

Crayfish are crustaceans that are also known as crawdads, crawfish, freshwater lobsters, mountain lobsters, mudbugs, or yabbies (Christoph et al., 2002). They are closely related to lobsters, crabs, and shrimp. There are about 150 crayfish species in North America, and over 540 species worldwide. Crayfish are eaten worldwide. Like other edible crustaceans, only a small portion of the body of a crayfish is eaten (Meyer-Rochow, 2009). Globally studies in Nigeria have shown that protein-energy malnutrition was the second cause of mortality and morbidity in children that were less than six years (WHO, 1998, 2002). Crayfish are usually prepared for consumption by smoking, and occasionally preserved by sun-drying, and is a common delicacy in the diet, among the people of the Southern and Western - Nigeria. Moreover, it may also be available at all the seasons, relatively cheap, affordable and suitable to supply adequate nutrients to cater for infants estimated daily nutrient requirements to 
Sustainability, Agri, Food and Environmental Research, (ISSN: 0719-3726), 9(2), 2021: 205-215 http://dx.doi.org/10.7770/safer-V0N0-art2257

eradicate protein- energy malnutrition (PEM), in the developing countries. Crayfish is classified as an animal polypeptide source, accounts for 36-45 per cent of crude protein, is a freshwater crustacean resembling small lobster, was reported to have high nutritive value with a superior biological value, true digestibility, net protein utilization, high content of essential amino acid, and protein efficiency is favourable compared to casein (FAO/WHO/UNU, 1985, 1998, 2002).

Nutritional information of crayfish has been highlighted to contain total fat of $1 \mathrm{~g}$, saturated fat $0 \mathrm{~g}$, cholesterol $0 \mathrm{~g}$,protein $126 \mathrm{mg}$, compared to one egg of $200 \mathrm{mg}$, sodium $170 \mathrm{mg}$, dietary fiber $0 \mathrm{mg}$, sugar $0 \mathrm{mg}$, calories of $80 \mathrm{mg}$ compared to beef $242 \mathrm{mg}$ calories, (SWAHN, 2004; Nahid et al., 2009).

In addition, health benefit of crayfish including supply of vitamin $D$ and $A$, also present were mineral elements such as calcium, potassium copper, zinc and iodine, (SWAHN, 2004; Nahid et al., 2009). It was reported to be highly pure, usually found in a clean lake that is free from industrial or water polluted environment, hence non-toxic for consumption, very low in carbohydrates, can be safely taken without gaining unnecessary weight. Apart medicinal value of crayfish, it is not only the delicate white meat, it taste is delicious, nutrientrich, can easily be absorb into the body and promotes the healing of post-operative wound granulation, (SWAHN, 2004; Nahid et al., 2009). It is in light of all these that the researcher seeks to evaluate the Nutrient and Anti-Nutrient Composition of Crayfish found along River Benue-Nigeria.

The search for alternative source of food nutrient remains a perpetual event as human population growth is dynamic and ever increasing under - exploitation and underutilization of abundant alternative natural resources has now been recognized as one of the militating factors against nutrient glut as intended by the 'creator'. Reliable satisfaction of an everincreasing market by the existing industry will require evaluation and eventual incorporation of alternative pond management practices. However, the ultimate success of this approach will depend on an understanding of specific nutritional composition of crayfish. The consumption of selected insects or crustaceans in diverse forms is a positive response to this imperative, that the problems of food malnutrition can be effectively overcome by using formulated feeds containing Crayfish. Hence, the present study is aimed at evaluating the nutrient and anti-nutrient composition of Crayfish found along River Benue - Nigeria.

This study intends to achieve a number of specific objectives namely; 1 ) assess the nutrition quality and constituents of animal (Crayfish) polypeptide using different nutrition test 
Sustainability, Agri, Food and Environmental Research, (ISSN: 0719-3726), 9(2), 2021: 205-215 http://dx.doi.org/10.7770/safer-V0N0-art2257

methods; 2) to determine the micronutrient composition of crayfish; 3) assess the antinutrient composition of Crayfish using different anti-nutrition test methods

\section{MATERIAL AND METHODS}

Study Area: The location for this study was Federal University of Agriculture, Makurdi Benue State, located in the mid-belt region of Nigeria with its capital in Makurdi. Benue state occupies a land mass of 34,059 sqkm with a total population of $4,253,641$. According to NDHS (2008) the total population of children in Benue State is 1,341102 . This makes Benue State the $9^{\text {th }}$ most populated state in Nigeria. Benue state lies within the lower river Benue trough in the middle belt region of Nigeria. It geographical coordinates are longitude $7^{\circ} 47^{i}$ and $10^{\circ} 0^{i}$ east. Latitude $6^{\circ} 25^{\mathrm{i}}$ and $8^{\circ} 8^{\mathrm{i}}$ North; and shares boundaries with five (5) other states namely; Nasarawa State to the North, Taraba State to the East, cross-River State to the South, Enugu State to the West. The state also shares a common boundary with the republic of Cameroon on Southeast. Benue state is blessed with abundant mineral resources; these resources are distributed in the local government areas of the state. Benue is the nation acclaimed food basket because of its rich agricultural produce which include yam, rice, beans, sorghum, millet, sesame cassava, sweet potatoes, maize, cocoyam. Agriculture is the main strain of the economy engaging over $75 \%$ of the state farming population. The state has one of the longest stretches of river systems in the country with great potential for viable fishing industry, dry season farming through irrigation.

Collection and Preparation of Samples: The species of native crayfish found in River Benue were collected with the use of mesh nets and further dried under the sun for 1 week and grounded into powder. The powder was then used for Proximate, micronutrient and antinutrient analysis.

Sample Analysis: Standard analytical procedures (AOAC, 2006) were used to determine the proximate composition, micronutrient composition and antinutrient composition. The crayfish sampled for vitamins and carotenoids, micronutrient and antinutritional analysis via HPLC following the methods of McGraw et al. (2006).

The samples were sun-dried to determine water content, and, ground samples were send for proximate analysis (crude protein, crude fat, crude fiber, ash) and for calcium (Ca), chloride (C1-), potassium (K), phosphorus $(P)$, magnesium $(\mathrm{Mg})$, sodium $(\mathrm{Na})$, sulfur $(\mathrm{S})$, 
Sustainability, Agri, Food and Environmental Research, (ISSN: 0719-3726), 9(2), 2021: 205-215 http://dx.doi.org/10.7770/safer-V0N0-art2257

copper ( $\mathrm{Cu})$, cobalt ( $\mathrm{Co})$, iron (Fe), manganese (Mn), molybdenum (Mo), and zinc ( $\mathrm{Zn}$ ) to Dairy One Forage Lab (Ithaca, NY).

Proximate Analysis: Analyses of all the processed crayfish were conducted to be certain that powdered form were within the range of values anticipated. Similar analyses were carried out on test powdered crayfish, and Nutrient to know the proximate moisture, ash, fibre, lipid, protein and carbohydrate contents. Analysis of the nutrient content of crayfish was carried out using the method of AOAC (2006).

Determination of Vitamins Composition: Vitamin A Retinol was determined using the method of (Henry, 1964). vitamin C ascorbic acid was determined using the method of AOAC (2006).

Mineral analysis: Mineral contents were determined using UNICAM solar 969 Atomic Absorption Spectrophotometer to analysis for elements such as $\mathrm{Mg}, \mathrm{Fe}, \mathrm{K}, \mathrm{Na}, \mathrm{Ca}$ and $\mathrm{P}$.

Anti-Nutrient Analysis - Tannin Determination: Tannin was extracted with ethyl acetate using soxhlet apparatus for about 3 hours. The solvent was distilled off and the residue repeatedly washed with petroleum ether $\left(40-60^{\circ} \mathrm{C}\right)$ until no more colour was extracted. The residue was then dissolved in $10 \mathrm{ml}$ ethyl acetate. To $5 \mathrm{ml}$ of the tannin extract were added $5 \mathrm{ml}$ Folin-Denis reagent and $10 \mathrm{ml}$ of saturated sodium carbonate solution. This was diluted to $5 \mathrm{ml}$ with distilled water and left standing for one hour. The absorbance of the resulting blue complex was read at $650 \mathrm{~nm}$ against a blank. This same treatment was given to the standard tannic acid and the concentration of tannin in the sample estimate from standard curve as described method above.

Phytic Acid Determination: The method used involved extraction of phytate and its conversion to ferric phytate, precipitation of ferric hydroxide from the ferric phytate, determination of iron in the sample and calculation of phytic acid from the resulting iron.

Oxalate determination: Oxalate was determined by extraction of the samples with water for about 3 hours and standard solutions of oxalic acid prepared and read on spectrophotometer (Spectronic20) at $420 \mathrm{~nm}$ using Wilson et al., (1982). The absorbance of the samples was also read and amount of oxalate estimated. Phytate was determined by titration with ferric chloride solution, while trypsin inhibitory activity was determined on casein and comparing the absorbance with that of trypsin standard solutions read at $280 \mathrm{~nm}$ (Makkar and Becker, 1996). 
Sustainability, Agri, Food and Environmental Research, (ISSN: 0719-3726), 9(2), 2021: 205-215 http://dx.doi.org/10.7770/safer-V0N0-art2257

Saponin determination: Saponin was also determined by comparing the absorbance of the sample extracts with that of the standard at $380 \mathrm{~nm}$ (Makkar and Becker, 1996). All the determinations were done in duplicates.

Data Analysis: The data were analyzed using SPSS version 20 at $5 \%$ level of significance. The mean and standard deviation of means (SDM) of the triplicate analysis of the sample were calculated.

\section{RESULTS}

Proximate analysis: Table 1 gives the percentage composition of the following parameters; protein, moisture, ash, fat and fibre for the crayfish studied. The data in Table 1 shows that crayfish has highest (9.54\%) percentage moisture content when compared with the values for the other parameters studied. The moisture content of crayfish is generally high which indicates that they cannot be preserved for a reasonable period of time without the risk of microbial deterioration and spoilage.

Table 1: proximate nutrient value analysis

\begin{tabular}{|c|c|c|c|c|c|c|}
\hline $\begin{array}{l}\text { Sample } \\
\text { (Nutrient) }\end{array}$ & & $\begin{array}{c}\text { Crude Protein } \\
\%\end{array}$ & $\begin{array}{c}\text { Crude fibre } \\
\%\end{array}$ & $\begin{array}{l}\text { Fat } \\
\%\end{array}$ & $\begin{array}{l}\text { Ash } \\
\%\end{array}$ & $\begin{array}{c}\text { Moisture } \\
\%\end{array}$ \\
\hline $\begin{array}{l}\text { Crayfish } \\
\text { gabonensis) }\end{array}$ & (Atya & $7.46 \pm 0.25$ & $5.60 \pm 1.73$ & $1.57 \pm 0.00 *$ & $2.47 \pm 0.00 *$ & $9.54 \pm 0.58$ \\
\hline
\end{tabular}

Values are means \pm standard deviation of triplicate determinations.

Source: Laboratory work

Mineral composition of crayfish (Atya gabonensis): Minerals concentrations are found in Table 2 below. All crayfish samples show extraordinarily high potassium, calcium and magnesium content, particularly relative to the phosphorus, zinc and iron content, most likely due to incorporation of this element into the chitinous exoskeleton. Stream-living crayfish displayed higher potassium and calcium content. 
Sustainability, Agri, Food and Environmental Research, (ISSN: 0719-3726), 9(2), 2021: 205-215 http://dx.doi.org/10.7770/safer-V0N0-art2257

Table 2: determination of mineral composition of crayfish (Atya gabonensis)

\begin{tabular}{lc}
\hline Mineral & Sample composition $(\mathrm{mg} / 100 \mathrm{~g})$ \\
\hline Potassium & $185.13 \pm 0.58$ \\
Calcium & $137.19 \pm 0.58$ \\
Phosphorus & $96.76 \pm 0.00$ \\
Magnesium & $36.55 \pm 0.58$ \\
Iron & $6.85 \pm 0.00$ \\
Zinc & $40.14 \pm 0.00$
\end{tabular}

Values are means \pm standard deviation of triplicate determinations.

Source: Laboratory work

Table 3: determination of vitamins composition of CRAYFISH (Atya gabonensis)

\begin{tabular}{ll}
\hline Vitamins & Sample composition $(\mathrm{mg} / 100 \mathrm{~g})$ \\
\hline Vitamin A & 0.872 \\
Vitamin B1 & 0.110 \\
Vitamin B2 & 0.651 \\
Vitamin B6 & 0.087 \\
Vitamin C & 4.920 \\
Vitamin E & 0.003 \\
Vitamin K & 0.006 \\
Vitamin D & 0.005 \\
\hline
\end{tabular}

Values are means of triplicate determinations.

Source: Laboratory work 
Sustainability, Agri, Food and Environmental Research, (ISSN: 0719-3726), 9(2), 2021: 205-215 http://dx.doi.org/10.7770/safer-V0N0-art2257

Table 4: phytochemical and anti-nutrient composition of crayfish (Atya gabonensis)

\begin{tabular}{|c|c|}
\hline Vitamins & Sample composition $(\mathrm{mg} / 100 \mathrm{~g})$ \\
\hline Saponin & 0.471 \\
\hline Alkaloid & 3.905 \\
\hline Flavonoid & 0.675 \\
\hline Turpentine & 0.027 \\
\hline Steroid & 0.046 \\
\hline Tannin & 0.017 \\
\hline Phenol & 0.021 \\
\hline Phytate & 0.060 \\
\hline Oxalate & 0.005 \\
\hline Trypsin inhibitor & 0.007 \\
\hline Glycoside & 0.001 \\
\hline
\end{tabular}

Values are means of triplicate determinations.

Source: Laboratory work

\section{DISCUSSION}

The result of the nutrient composition of crayfish along River Benue revealed that the moisture value $(94.57 \%)$ was the highest while fat was the least $(1.54 \%)$. Moistures or water is a universal solvent. It dissolves other substances, carries nutrients and other materials round the body, making it possible for every organ to perform its functions effectively (McDonald et al., 1998).

The availability of such high crude protein in investigated species indicates their high nutritive value. This confirms the findings of Brige \& Juday (1922); Orr (1934a \& b) and Dabrowski et al. (1966). 
Sustainability, Agri, Food and Environmental Research, (ISSN: 0719-3726), 9(2), 2021: 205-215 http://dx.doi.org/10.7770/safer-V0N0-art2257

Ash content of an animal based food is the function of the mineral elements present. Phytic acid, a hexaphosphate derivative of inositol is an important, storage form of phosphorus. It causes calcium and zinc deficiency in man when in excess, the deficiency of these minerals results in Oteo-malacia, anaemia and rickets. However, it plays an important role in determining starch digestibility in food. High content of tannin decrease protein quality by decreasing digestibility and causes damage to the intending track (Butter, 1989). Dutta (2003) said that tannins are responsible for the flavour in tea and it use in the treatment of skin eruption and for other medicinal purposes due to their astringent properties.

Calcium (Ca) is an important factor in fibronectin in formation which forms fibrinogen and subsequently fibrin and collagen. Fibrin is a dotting factor responsible for homeostasis. Potassium is a known activator of energy potentials across nerve membrane together with calcium, ions may serve as replenishment in diarrheic conditions, maintenance of normal nervous function and gut peristalsis. Magnesium ions are known hormone activators in type 2 diabetes, their presence in these crayfish can be beneficial in managing this disease.

Phytic acid, a hexaphosphate derivative of inositol is an important, storage form of phosphorus. It causes calcium and zinc deficiency in man when in excess, the deficiency of these minerals results in Oteo-malacia, anemia and rickets. However, it plays an important role in determining starch digestibility in food. High content of tannin decrease protein quality by decreasing digestibility and causes damage to the intending track (Butter, 1989). Dutta (2003) said that tannins are responsible for the flavour in tea (turn-brown) and it use in the treatment of skin eruption and for other medicinal purposes due to their astringent properties.

This study has, therefore, established the fact that crayfish (Atya gabonensis) along River Benue contains highly beneficial contents which can be exploited beneficially in healthcare services and nutritional supplement.

As conclusions, the amount of information concerning the nutrition of crayfish species is limited. A definition of nutritional requirements based upon research with purified specie of crayfish appears to be the first step. As appeared from the table of the results of these analyses, it can be concluded that crayfish contain higher concentration of protein needed for body growth and repairs of damaged cells.

As recommendations, these data provide preliminary detail on the nutrient and antinutrient composition of crayfish but clearly species, size, and habitat variables influence the composition of this prey item in ways that require much further investigation. 
Sustainability, Agri, Food and Environmental Research, (ISSN: 0719-3726), 9(2), 2021: 205-215 http://dx.doi.org/10.7770/safer-V0N0-art2257

\section{REFERENCES}

AOAC (1984). Official Method of Analysis of the Association of official Analytical Chemists. Washington D. C. USA. Pp 832-860.

Brige, E.A. \& Juday, G. (1922). The inland lakes of Wisconsin. The plankton. I. Its quantity and chemical composition. Nat, Hist. Surv Bull. 64 Sci. ser. No. 13: 1-222.

Butter, L. G. (1989). Effects of Condensed Tannins on animal nutrition in chemistry and significance of condensed tannins. R. W. Hermingway and J. J. Karchesy Eds. Plenum press. New York. Pp 391 - 402.

Christoph, N., Johannes, P., Peter, S. and Bernd S. (2003). Plants and Animals (Pflanzen und Tiere). Leipzig: Urania Verlag.

Dabrowski, T.; Kolakowski, E.; Wawreszuk, H. \& Choroszucha. CZ. (1966). Studies on chemical composition of American Crayfish \{Orcomcies Hmosus) meat as related to its nutritive value. J. Fish. Res. Bd. Canada, 25:1653-1662.

Dutta, A. C. (2003). Botany for Degree students (6th edu). Oxford University press. pp 140 $-143$.

FAO/WHO/UNU $((1985,1998,2002)$ Preparation and use of Food-Based Dietary Guidelines. Report of a Joint.FAO/WHO Consultation. WHO Technical Report series 880. Geneva.

Makkar, H.P. and K Becker, K. (1996). Nutritional value and anti-nutritional components of whole and ethanol extracted Moringa oleifera leaves. Animal Feed Science and Technology 63: 211-228.

McDonald, P.; Edwards, R. A.; Greenhalgh, J. F. D. and Morgan, C. A. (1998). Animal nutrition (5th.ed). Longman, London, 607pp

McGraw, K. J., Nolan, P. M. and Crino, O. L. (2006). Carotenoid accumulation strategies for becoming a colorful house finch: analyses of plasma and liver pigments in wild molting birds. Funct. Ecol. 20:678-688.

Meyer-Rochow, V. B. (2009). "Food taboos: their origins and purposes". Journal of Ethnobiology and Ethnomedicine. 5-18

Nahid, F., Zaglol,I. and Fayza, E. (2009): Study on Chemical Quality And Nutrition Value of Fresh Water Cray Fish (Procambarus Clarkii) Journal of The Arabian Aquaculture Society 4 (1)1-18

NDHS (2008). Nigeria Demographic and Health Survey. National Population Commission, Federal Republic of Nigeria Abuja, Nigeria. Measure DHS, ICF Macro Calverton, Maryland, USA. 
Orr, A. P. (1934a). The weight and chemical composition of Euchaeta norvegica Boeck* Proc, Roy Sec. Edinb. B. 54: 51-55.

SWAHN, J.O. (2004). The Cultural History Of Crayfish Bull. Fr. Pêch Bull. Fr. Pêche Piscic. 372-373: 243-251-243.

Wheeler, E.I. and Ferrel, R.E. (1971). Methods for phytic acid determination in wheat and wheat fractions. Cereal Chem., 84: 312-320.

WHO (2002). Global strategy for Infant and young child feeding. WH/A55/2002/REC/1 Annex 2. Geneva.

Wilson, C.W., Shaw, P.E. and Knight, R.J. (1982). Analysis of oxalic acid in carambola (Averhoa carambola L.) and spinach by HPLC. Journal of Agricultural and Food Chemistry, 30; 1106.

World Health Organization (1998, 2002) Complementary feeding of young children in developing countries: a review of current scientific knowledge, Geneva, Switzerland.

Orr, A. P. (1934b). On the biology of Calartus finmarchicus part IV. Seasonal changes in the weight and chemical composition in lochfyne. J. mar. bioL Ass. U. K.,VP;631-632.

Received: 09th Jule 2020; Accepted: 02 ${ }^{\text {th }}$ January 2021;

First distribution: 07th January 2021. 